\title{
Faktor-Faktor yang Mempengaruhi Kewajiban Pengungkapan dalam Laporan Keuangan: Studi Empiris pada Perusahaan Pulp dan Kertas yang Terdaftar di BEI
}

\author{
Fidiatur Fitrifiani ${ }^{1}, \operatorname{Ridwan}^{2 *}$ \\ 1,2 Program Studi Akuntansi, STIE Bhakti Prasetya Karya Praja, Jakarta \\ $2^{2 *}$ coresponding author's email: ridwan.8900@gmail.com
}

\begin{abstract}
Abstrak. This study objectives to determine the factors that affect mandatory disclosure in the financial statements consisting of leverage, liquidity, profitability, public share ownership, and company status. The data used in this study are secondary in the form of financial reports and annual reports. The number of companies studied was eight companies in 2013-2017 and the number of samples is counted to 40 observations. The sampling method used in this study was purposive sampling using certain criteria. The analysis technique used is panel data regression analysis, estimation test for model selection, classic assumption test with a hypothesis test. The results of the research analysis showed that partial leverage, liquidity, profitability, and public share ownership had no significant and negative effect on mandatory disclosure in the financial statements while company status did not have a significant effect but had a positive direction mandatory disclosure in the financial statement.
\end{abstract}

Kata kunci: leverage, liquidity, profitability, public share ownership, company status, mandatory disclosure in the financial statement.

\section{Pendahuluan}

Industri Pulp dan kertas adalah salah satu sektor unggulan yang terus dipacu dan didukung pengembangannya karena memiliki ketersediaan bahan baku dan pasar domestik yang cukup besar serta didukung dengan penerapan teknologi canggih. Pada tahun 2017, menurut Kementrian Perindustrian industri Pulp dan kertas di dalam negeri akan memiliki potensi pertumbuhan yang cukup signifikan. Salah satu faktor pendorongnya adalah upaya pemerintah yang mengusulkan agar sektor ini masuk dalam kelompok sektor industri yang mendapatkan harga gas kompetitif. Pengembangan industri Pulp dan kertas di dalam negeri cukup terbuka karena didukung dengan ketersedian sumber bahan baku kayu dari hutan tanaman industri dan hutan rakyat serta bahan baku non kayu. Kemenperin juga ingin memacu insutri Pulp dan kertas untuk terus menggunakan teknologi terkini agar dapat menghasilkan inovasi 


\section{Buana Akuntansi}

FIDIATUR \& RIDWAN

Vol. 5 No. 1

ISSN 2528-1119

E-ISSN 2580-5452

(Kementerian Perindustrian RI, 2016). Terkait dengan pernyataan Aryan, ketua umum Asosiasi Pulp dan Kertas Indonesia (APKI) bahwa para era digital seperti sekarang ini berpengaruh terhadap pertumbuhan pasar industri kertas cetak yang sedikit melambat, karena sekarang tidak dipungkiri orang sudah cenderung beralih ke digital. Namun masih bisa tumbuh $5 \%$ pada tahun depan. Hanya saja Arya menilai rantangannya bagi Indonesia, yakni masih dituduh melakukan aksi dumping Pulp (Ant, Jurnalis, 2018). Langkah yang sejalan dengan implementasi Making Indonesia 4.0 ini dinilai dapat meningkatkan daya saing produk nasional sehingga lebih kompetitif di pasar global yaitu salah satunya dengan menggunakan teknologi terkini yang ramah lingkungan. Menurut Kepala Badan Penelitian dan Pengembangan Industri (BPPI) Indonesia berada di peringkat ke-9 untuk produsen Pulp terbesar di dunia serta posisi ke-6 untuk produsen kertas terbesar di dunia. Industri Pulp dan kertas juga merupakan salah satu sektor yang mendapat prioritas dalam pengembangannya karena memiliki potensi terutama terkait bahan baku yang produktivitas tanamannya jauh lebih tinggi dibandingkan dengan negara-negara pesaing yang beriklim tropis (Badan Litbang Kementerian Perindustrian, 2018). Kondisi ini mendorong perusahaan untuk lebih transaparan dalam mengungkapkan laporan keuangannya guna menarik investor, khususnya bagi perusahaan yang melakukam penawaran umum kepada publik atau go public. Salah satu sarana bagi perusahaan untuk memperoleh modal demi kelangsungan usahanya adalah melalui pasar modal. Dalam melakukan aktivitas di pasar modal para pelaku pasar mendasarkan keputusannya pada informasi yang diterima. Salah satunya adalah laporan keuangan (BEI, 2015). Dalam praktiknya ternyata masih banyak perusahaan go public yang terlambat dalam melaporkan laporan keuangannya, yaitu tidak sesuai dengan tenggat waktu yang telah diatur. Data per September 2018 tercatat bahwa 40 emiten terlambat menyampaikan laporan keuangan tengah tahunan. Sebanyak 5 perusahaan sudah dikenakan denda peringatan tertulis dan denda Rp50.000.000,00 atau total Rp250.000.000,00 akibat lalai menyampaikan kinerja semester I 2018 (Dani Jumadil Akhir, Jurnalis, 2018).

Laporan keuangan pada dasarnya adalah proses akuntansi yang dapat digunakan sebagai alat mengkomunikasikan data keuangan atau aktivitas perusahaan kepada pihak-pihak yang berkepentingan. Pihak-pihak yang berkepentingan terhadap posisi keuangan maupun perkembangan perusahaan dibagi menjadi dua, yaitu pihak internal seperti manajemen perusahaan dan karyawan,dan yang kedua adalah pihak eksternal seperti pemegang saham, investor, kreditor, pemerintah dan masyarakat. Sehingga dapat disimpulkan bahwa laporan keuangan merupakan alat informasi yang menghubungakan perusahaan dengan pihak-pihak yang berkepentingan (Hery, 2017, hal. 19). Laporan keuangan merupakan jembatan antara pihak internal yaitu manajemen dan pihak eksternal seperti kreditur, investor dan pemerintah. Laporan keuangan mempunyai fungsi sebagai penyedia informasi yang menyangkut posisi keuangan, kinerja, serta perubahan posisi keuangan suatu perushaan yang bermanfaat bagi sejumlah besar pemakai dalam pengambilan keputusan ekonomi (Harahap, 2009).

Proses pembuatan laporan keuangan tidak lepas dari kelengkapan pengungkapan (disclousure). Hal ini sangat penting untuk dilakukan karena akan memberikan gambaran kondisi suatu perusahaan serta mampu menunjukan sifat perbedaan kelangkapan pengungkapan antar perusahaan. Pengungkapan (disclouure) yang disampaikan oleh perusahaan harus benar-benar bermanfaat, karena jika tidak bermanfaat maka tujuan dari pengungkapan tersebut tidak tercapai. Apabila dikaitkan dengan laporan keuangan harus memberikan informasi dan penjelasan yang memadai mengenai hasil aktivitas suatu perusahaan. Banyaknya informasi yang disajikan dalam laporan keuangan tergantuk dari pihakpihak pengguna atau yang membutuhkan dan sesuai peraturan yang berlaku agar penyajian bisa bermanfaat dan mudah dipahami (Astina M., Hardi, \& A., 2017). Prinsip akuntansi tentang tingkat pengungkapan dikenal prinsip full disclosure agar laporan keuangan dapat menyajikan 
informasi secara penuh atau full. Namun, prinsip ini dijabarkan lagi dalam berbagai standar lain yang mengaturnya. Secara umum ada 3 (tiga) pengertian dalam disclosure (pengungkapan), yaitu full disclosure diartikan bahwa informasi disajikan secara penuh sedangkan adequate sepantasnya dan fair seperlunya sedangkan dalam kualitas informasi keuangan yang diberikan oleh perusahaan terdapat 2 (dua) jenis pengungkapan (discloure) yang diterbitkan oleh perusahaan (Harahap, 2009).

Pengungkapan tersebut adalah kewajiban pengungkapan (mandatary discloure) merupakan pengungkapan minimum mengenai informasi yang harus di ungkapkan oleh perusahaan melalui peraturan pemerintah dan pengungkapan sukarela (voluntary discloure) merupakan pengungkapan yang dilakukan perusahaan di luar apa yang diwajibkan oleh standar akuntansi atau peraturan badan pengawas. Pengungkapan laporan keuangan yang memadai dapat ditempuh melalui penerapan informasi yang baik. Untuk menyelenggarakan informasi yang baik bagi pelaku pasar modal, maka pemerintah menunjuk Badan Pengawas Pasar Modal (Bapepam) yang sejak tahun 2011 digantikan perannya oleh Otoritas Jasa Keuangan (OJK) melalui Undang-Undang Republik Indonesia Nomor 21 Tahun 2011. Sesuai dengan Peraturan Otoritas Jasa Keuangan Nomor 29/Pojk.04/2016 tentang Laporan Tahunan Emiten atau Perusahaan Publik, perusahaan wajib menyampaikan Laporan Tahunan kepada Otoritas Jasa Keuangan paling lambat pada akhir bulan keempat setelah tahun buku berakhir. Laporan tersebut dapat berupa laporan keuangan (financial statement) ataupun laporan tahunan (annual report) (OJK, 2016).

Faktor-faktor dalam pengungkapan (disclosure) laporan keuangan dibagi menjadi 2 (dua) yaitu faktor-faktor keuangan dan non keuangan. Faktor-faktor keuangan meliputi leverage, likuiditas, profitabilitas, ukuran perusahaan, common stock ratio, pendapatan per share dan margin laba bruto. Sedangkan faktor-faktor non keuangan meliputi porsi saham publik, porsi saham asing, umur perusahaan, Status Perusahaan, nilai perusahaan, jenis industri, penerbitan sekuritas, waktu terdaftar dan persentase kepemilikan manajerial. Rasio leverage merupakan rasio yang digunakan untuk mengukur sejauh mana aktiva perusahaan dibiayai dengan utang. Artinya besarnya jumlah utang yang digunakan perusahaan untuk membiayai kegiatan usahanya jika dibandingkan dengan menggunakan modal sendiri.

Rasio Likuiditas merupakan rasio yang menggambarkan kemampuan perusahaan dalam memenuhi kewajiban jangka pendeknya. Fungsi lain rasio likuiditas adalah untuk menunjukkan atau mengukur kemampuan perusahaan dalam memenuhi kewajibannya yang sudah jatuh tempo. Luas kewajiban pengungkapan laporan keuangan diperoleh hasil bahwa secara parsial tidak berpengaruh signifikan yang disebabkan oleh rasio likuiditas minimum tetapi luas pengungkapan di atas rata-rata. Likuiditas dipandang sebagai ukuran kinerja manajemen dalam mengelola perusahaan. Perusahaan dengan tingkat likuiditas rendah akan melakukan pengungkapan yang lebih luas terhadap informasi lain sebagai upaya untuk menutupi kondisi likuiditasnya yang rendah (Pradipta, Topowijono, \& Azizah, 2016).

Rasio Profitabilitas adalah rasio yang menilai kemampuan perusahaan dalam mencari keuntungan atau laba dalam suatu periode tertentu. Rasio ini juga memberi ukuran tingkat efektivitas manajemen suatu perusahaan yang ditunjukkan dari laba yang dihasilkan dari penjualan atau dari pendapatan investasi. Persentase saham yang ditawarkan kepada publik menunjukkan besarnya private information yang harus dibagikan manajer kepada publik, perhitungan ini tidak sebatas hanya berdasarkan pendapatan atau penjualan, dapat berupa feedback rate yang dihasilkan dalam bentuk return kepada investor (Yanti, 2018).

Private information tersebut merupakan informasi internal yang semula hanya diketahui oleh manajer seperti: standar yang dipakai dalam pengukuran kinerja peusahaan, keberadaan perencanaan bisnis dan sebagainya. Dengan adanya publik investor mengakibatkan manajer berkewajiban memberikan informasi internal secara berkala sebagai bentuk 
pertanggungjawabannya. Porsi saham publik memberikan kontribusi sebesar $91,8 \%$ dalam mempengaruhi perubahan kelengkapan pengungkapan laporan keuangan (Wahyuningsih, Arifati, \& Raharjo, 2016) sementara porsi saham publik tidak berpengaruh terhadap pengungkapan laporan keuangan (Astina M., Hardi, \& A., 2017).

Beberapa penelitian yang telah dilakukan mengenai kewajiban pengungkapan laporan keuangan antara lain: (1) Pengaruh Ukuran Perusahaan leverage,Profitabilitas dan LikuiditasTerhadap Luas Kewajiban pengungkapan Laporan Keuangan (Studi Empiris Pada Perusahaan Manufaktur Yang Terdaftar di BEI Tahun 2013-2014) yang menyimpulkan bahwa semua variabel secara simultan berpengaruh signifikan terhadap luas kewajiban pengungkapan. Variabel ukuran perusahaan berpengaruh positif signifikan sedangkan variabel leverage, profitabilitas dan likuiditas tidak berpengaruh signifikan terhadap luas kewajiban pengungkapan laporan keuangan (Pradipta, Topowijono, \& Azizah, 2016); (2) Pengaruh Likuiditas, leverage, Profitabilitas, Porsi Saham Publik, Ukuran Perusahaan dan Umur Perusahaan Terhadap Kelengkpan Pengungkapan Laporan Keuangan Pada Perusahaan Manufaktur Yang Terdaftar di Bursa Efek Indonesia Dengan Periode Penelitian Tahun 2009_ 2014 yang menyimpulkan bahwa variabel rasio likuiditas, leverage, profitabilitas, porsi saham publik, ukuran perusahaan dan umur perusahaan memberikan kontribusi sebesar $91,8 \%$ dalam mempengaruhi perubahan kelengkapan pengungkapan laporan keuangan, sedangkan 8,2\% dipengaruhi oleh faktor lain yang tidak diteliti dalam penelitian ini (Wahyuningsih, Arifati, \& Raharjo, 2016); dan (3) Faktor-Faktor Yang Mempengaruhi Kelengkapan Pengungkapan Laporan Keuangan Pada Perusahaan Manufaktur Yang Terdaftar Di BEI Tahun 2011-2013 yang menyimpulkan bahwa profitabilitas berpengaruh terhadap kelengkapan pengungkapan laporan keuangan sedangkan yang tidak berpengaruh terhadap kelengkapan pengungkapan laporan keuangan adalah leverage, likuiditas, porsi saham publik dan umur perusahaan. Besarnya pengaruh variabel independen terhadap variabel dependen yaitu sebesar 1,6\% (Astina M., Hardi, \& A., 2017).

Melihat dari hasil penelitian-penelitian yang terdahulu, penelitian ini kembali menguji kewajiban pengungkapan dalam laporan keuangan perusahaan Pulp dan Kertas dengan 3 (tiga) faktor yaitu leverage, likuiditas dan profitabilitas serta 2 (dua) faktor non-keuangan yaitu struktur kepemilikan saham publik dan status perusahaan. Kelima faktor ini dipilih karena penelitian-penelitian terdahulu masih menunjukkan hasil yang tidak konsisten. Subjek penelitian dipilih karena perusahaan Pulp dan Kertas merupakan industri yang memiliki potensi sangat besar serta berkembang sangat pesat sehingga banyak investor yang tertarik dan membeli saham perusahaan tersebut.

\section{Tinjauan Pustaka}

\subsection{Teori Agensi}

Teori keagenan pada intinya membahas hubungan manajemen sebagai agen dan pemegang saham sebagai principal. Prinsipal menyediakan fasilitas dan dana untuk menjalankan perusahaan. Teori agensi (keagenan) adalah konsep yang mendeskripsikan hubungan antara prinsipal (pemberi kontrak) dan agen (penerima kontrak), prinsipal mengontrak agen untuk bekerja demi kepentingan atau tujuan prinsipal sehingga prinsipal memberikan wewenang pembuatan keputusan kepada agen untuk mencapai tujuan tersebut. Agen bertanggungjawab atas pencapaian tujuan tersebut dan agen menerima balas jasa dari prinsipal. Dalam organisasi perusahaan, prinsipal adalah para pemegang saham dan agen adalah manajemen puncak (dewan komisaris dan direksi), prinsipal dapat juga manajemen puncak dengan manajemen pusat pertanggungjawaban dalam organisasi. Biasanya, semakin tinggi pencapaian tujuan prinsipal maka semakin tinggi pula balas jasa yang diterima oleh agen. 


\section{Buana Akuntansi}

FIDIATUR \& RIDWAN

Vol. 5 No. 1

ISSN 2528-1119

E-ISSN 2580-5452

Salah satu hal yang sangat penting dalam teori keagenan adalah desentralisasi atau pendelegasian wewenang pembuatan keputusan dari prinsipal kepada agen. Hubungan keagenan diharapkan dapat menciptakan keselarasan antara prinsipal dan agen. Namun, di antara keduanya mungkin masih terjadi perbedaan mencapai tujuannya masing-masing sehingga diperlukan sistem pengendalian. Sistem pengendalian digunakan oleh prinsipal agar agen membuat keputusan sesuai dengan harapan prinsipal, yaitu dapat mencapai tujuan prinsipal (Supriyono, 2018, hal. 63). Oleh karena itu, perusahaan dituntut melakukan pengungkapan informasi keuangan dan informasi relevan lainnya dalam laporan keuangan tahunan karena pengungkapan merupakan aspek penting akuntansi keuangan. Informasi tersebut berguna bagi para pemakai terutama investor untuk pengambilan keputusan.

\subsection{Teori Akuntansi Positif}

Teori akuntansi positif didasarkan pada posisi bahwa pemegang saham, manajer, dan regulator (politisi) adalah rasional dan mereka juga berusaha untuk memaksimalkan utility mereka, yang secara langsung terkait dengan kompensasi dan kemakmuran mereka. Pilihan akuntansi tergantung pada variabel-variabel yang mempresentasikkan insentif manajemen untuk memilih metode akuntansi dengan rencana bonus, kontrak hutang, dan proses politisi. Teori akuntansi positif menjelaskan suatu proses yang menggunakan kemampuan, pemahaman dan pengetahuan akuntansi serta penggunaan kebijakan akuntansi yang dapat digunakan untuk menghadapi kondisi tertentu dimasa yang akan datang (Mawardi, 2018). Teori akuntansi positif mempunyai tiga hubungan keagenan. Pertama, hubungan manajemen dengan pemilik (pemegang saham) manajemen akan cenderung menerapkaan akuntansi yang kurang konservatif atau optimis apabila kepemilikan saham yang ada di perusahaan lebih rendah dibandingkan dengan kepemilikan saham eksternal. Kedua, hubungan dengan kreditor apabila rasio hutang atau ekuitas perusahaan tinggi maka kemungkinan bagi manajer untuk memilih metode akuntansi yang konservatif atau yang cenderung menurunkan laba semakin besar. Ketiga, hubungan manajemen dengan pemerintah yaitu manajer akan cenderung melaporkan laba secara konservatif atau secara hati-hati untuk menghindari pengawasan yang lebih ketat dari pemerintah, para analis, dan masyarakat (Chariri \& Ghozali, 2014).

\subsection{Analisis Laporan Keuangan}

Analisis laporan keuangan adalah aplikasi dari alat dan teknik analitis untuk laporan keuangan bertujuan umum dan data-data yang berkaitan utuk menghasilkan estimasi dan kesimpulan yang bermanfaat dalam analisi bisnis. Analisis laporan keuangan mengurangi ketergantungan pada firasat, tebakan, dan intuisi dalam pengambilan keputusan, serta mengurangi ketidakpastian analisi bisnis (Subramanyam, 2014, hal. 4). Tujuan utama analisis laporan keuangan adalah agar dapat mengetahui posisi keuangan perusahaan saat ini. Dengan mengetahui posisi keuangan, setelah dilakukan analisis laporan keuangan secara mendalam, akan terlihat apakah persahaan dapat mencapai target yang telah direncanakan sebelumnya atau tidak. Hasil analisis laporan keuangan juga dapat memberikan infornasi tentang kelemahan dan kekuatan yang dimiliki perusahaan (Kasmir, 2016, hal. 66). Tujuan dan manfaat analisis laporan keuangan secara umum adalah:

1) Untuk mengetahui posisi keuangan dalam satu periode tertentu, baik harta, kewajiban, modal, maupun hasil usaha yang telah dicapai untuk beberapa periode.

2) Untuk mengetahui kelemahan-kelemahan apa saja yang menjadi kekurangan perusahaan.

3) Untuk mengetahui kekuatan-kekuatan yang dimiliki.

4) Untuk mengetahui langkah-langkah perbaikan apa saja yang perlu dilakukan kedepan yang berkaitan dengan posisi keuangan perusahaan saat ini. 


\section{Buana Akuntansi}

5) Untuk melakukan penilaian kinerja manajemen kedepan apakah perlu penyegaran atau tidak karena sudah dianggap berhasil atau gagal.

6) Dapat juga digunakan sebagai pembanding dengan perusahaan sejenis tentang hasil yang mereka capai (Kasmir, 2016, hal. 68).

\subsection{Pengungkapan Laporan Keuangan}

Menurut Wolk et al. (1991), "Pengungkapan merupakan informasi yang ada didalam laporan keuangan maupun komunikasi pelengkap yang mencakup catatan kaki, peristiwa setelah pelaporan, analisis manajemen tentang operasi yang akan datang, peramalan keuangan dan operasi, dan laporan keuangan tambahan. Laporan keuangan dan komunikasi pelengkap tersebut disebut sebagai pelaporan keuangan (financial reporting) (Adhani \& Subroto, 2013). Lebih lanjut, istilah disclosure memiliki arti tidak menutupi atau tidak menyembunyikan. Disclosure berarti memberikan data yang bermanfaat kepada pihak yang ememerlukan. Jadi data tersebut harus benar-benar bermanfaat, karena apabila tidak bermanfaat, tujuan dari pengungkapan tersebut tidak akan tercapai. Apabila dikaitkan dengan laporan keuangan, disclosure mengandung arti bahwa laporan keuangan harus memberikan informasi dan penejelasan yang cukup mengenai hasil aktifitas perusahaan. Dengan demikian, informasi tersebut harus lengkap, jelas, dan dapat menggambarkan secara tepat mengenai kejadian-kejadian ekonomi yang berpengaruh terhadap hasil operasi setiap unit usaha tersebut. Informasi yang diungkapkan harus bermanfaat dan tidak membingungkan pemakai laporan keuangan dalam membantu pengambilan keputusan ekonomi. Berapa banyak informasi yang harus diungkapkan tidak hanya tergantung pada keahlian pembaca, tetapi juga pada standar yang dibutuhkan (Chariri \& Ghozali, 2014, hal. 407).

Tujuan dari pelaporan keuangan yang terdapat dalam PSAK No.1 yaitu pelaporan keuangan memberikan informasi yang bermanfaat bagi investor dan kreditor, dan pemakai lainnya dalam mengambil keputusan investasi, kredit dan yang serupa secara rasional. Informasi tersebut harus bersifat komprehensif bagi mereka yang memiliki pemahaman yang rasional tentang kegiatan bisnis dan ekonomi memliki kemamuan unutk empelajari informasi dengan cara yang rasional (Chariri \& Ghozali, 2014, hal. 412). Dalam mengungkap laporan keuangan ada 3 (tiga) klausul yang umum diusulkan, yaitu:

1) Pengungkapan cukup (adequate disclosure), yaitu pengungkapan mininum yang disyaratkan peraturan yang berlaku.

2) Pengungkapan wajar (fair disclosure), yaitu pengungkapan yang bertujuan etis agar memberikan perlakuan yang sama kepada semua pemakai laporan dengan menyediakan informsai yang layak terhadap pembaca potensial.

3) Pengungkapan lengkap (full disclosure), yaitu pengungkapan masih menyangkut kelengkapan penyajian informasi yang diungkap secara relevan. Pengungkapan penuh bisa memiliki kesan enyajian informasi yang elimpah seghingga beberapa pihak menganggapnya tidak baik. Bagi beberapa pihak pengungkapan secara lengkap dapat diartikan sebagai penyajian informasi yang melimpah dan berlebihan oleh karena itu di anggap tidak layak (Kasmir, 2016).

Untuk memenuhi tingkat pengungkapan laporan keuangan yang memadai maka pemerintah melaksanakan regulasi informasi bagi para pelaku pasar modal melalui UU pasar modal, Badan Pengawas Pasar Modal (Bapepam), Bursa efek Indonesia (BEI), Ikatan Akuntansi Indonesia (IAI) serta Otoritas Jasa Keuangan (OJK).

\subsection{Faktor-Faktor Yang Mempengaruhi Pengungkapan Laporan}

Faktor- faktor dalam pengungkapan (disclosure) laporan keuangan dibagi manjadi 2 (dua) yaitu faktor-faktor keuangan dan non keuangan. Faktor-faktor keuangan meliputi leverage, 


\section{Buana Akuntansi}

likuiditas, profitabilitas, ukuran perusahaan, common stock ratio, pendapatan per share dan margin laba bruto. Sedangkan faktor-faktor non keuangan meliputi porsi saham publik, porsi saham asing, umur perusahaan, Status Perusahaan, nilai persentase, jenis industri, penerbitan sekuritas, waktu terdaftar dan persentase kepemilikan manajerial. Dalam penelitian ini variabel yang digunakan dibatasi oleh peneliti khususnya pada variabel antara lain yaitu leverage, likuiditas, profitabilitas,kepemilikan saham publik dan status perusahaan.

Leverage atau solvabilitas merupakan rasio yang digunakan untuk mengukur sejauh mana aktiva perusahaan dibiayai dengan utang. Artinya besarnya jumlah utang yang digunakan perusahaan untuk membiayai kegiatan usahanya jika dibandingkan dengan menggunakan modal sendiri. Dalam arti luas dikatakan bahwa rasio leverage digunakan untuk mengukur kemampuan perusahaan untuk membayar seluruh dibubarkan (dilikuidasi). Semakin tinggi leverage suatu perusahaan berarti semakin tinggi pula ketergantungan perusahaan tersebut kepada krediturnya.

Menurut Fred Weston menyebutkan bahwa rasio likuiditas (liquidity ratio) merupakan rasio yang menggambarkan kemampuan perusahaan dalam memenuhi kewajiban (utang) jagka pendek. Artinya apabila perusahaan ditagih, perusahaan akan mampu untuk memenuhi utang tersebut terutama utang yang sudah jatuh tempo. Dengan kata lain, rasio likuiditas berfungsi untuk menunjukkan atau mengukur kemampuan perusahaan dalam memenuhi kewajibannya yang sudah jatuh tempo, baik kewajiban kepada pihak luar perusahaan (likuiditas badan usaha) maupun di dalam perusahaan (likuiditas perusahaan) (Kasmir, 2016, hal. 129). Rasio likuiditas yang sering juga disebut dengan rasio modal kerja merupakan rasio yang digunakan untuk mengukur seberapa likuidnya suatu perusahaan. Caranya adalah dengan membandingkan komponen yang ada di neraca, yaitu total aktiva lancar dengan total passiva lancar (utang jangka pendek). Penilaian dapat dilakukan untuk beberpa periode sehingga terlihat perkembangan likuiditas perusahaan dari waktu ke waktu.

Profitabilitas adalah kemampuan suatu perusahaan untuk memperoleh keuntungan (profit). Profitabilitas bertujuan untuk mengukur efisiensi aktivitas perusahaan dan kemampuan perusahaan untuk memperoleh keuntungan tersebut pengelola perusahaan harus mampu bekerja secara efisien serta kinerja perusahaan harus senantiasa ditingkatkan. Perusahaan dengan profitabilitas tinggi akan melakukan pengungkapan laporan keuangan secara berlebih. Semakin tingginya rasio profitabilitas perusahaan, menunjukkan semakin tingginya kemampuan perusahaan dalam memperoleh laba dan semakin baik kinerja perusahaannya. Dengan laba yang tinggi perusahaan memiliki cukup dana untuk mengumpulkan, mengelompokkan dan mengolah informasi menjadi lebih bermanfaat serta dapat menyajikan pengungkapan yang lebih komprehensif. Oleh karena itu perusahaan dengan profitabilitafs yang tinggi akan lebih berani mengungkapkan laporan. Dengan demikian semakin tinggi profitabilitas perusahaan maka akan semakin luas pengungkapan laporan keuangannya.

Struktur kepemilikan merupakan bentuk komitmen dari pemegang saham untuk mendelegasikan pengendalian dengan tingkat tertentu kepada para manajer. Penggunaan struktur kepemilikan digunakan untuk menunjukkan bahwa variabel-variabel yang penting dalam struktur modal tidak hanya ditentukan oleh hutang dan ekuitas saja tetapi juga ditentukan oleh persentasi kepemilikan saham oleh manajemen dan institusi. Persentase saham yang ditawarkan kepada publik menunjukkan besarnya private information yang harus dibagikan manajer kepada publik. Private information tersebut merupakan informasi internal yang semula hanya diketahui oleh manajer, sepert standar yang dipakai dalam pengukuran kinerja perusahaan, keberadaan perencanaan bonus, dan sebagainya. Dengan adanya public investor mengakibatkan manajer berkewajiban memberikan memberikan informasi internal secara berkala sebagai bentuk pertanggungjawabannya. Semakin besar persentase saham yang ditawarkan kepada publik, maka semakin besar pula informasi internal yang harus diungkapkan 


\section{Buana Akuntansi}

kepada publik, sehingga kemungkinan dapat mengurangi intensitas terjadinya earnings management. Tujuan perusahaan yaitu meningkatkan nilai perusahaan maka diperlukan pendanaan eksternal. Sumber pendanaan eksternal diperoleh dari saham masyarakat.

Latar belakang masuknya variabel Status Perusahaan didorong oleh suatu alasan sederhana yaitu bahwa perusahaan dengan status yang berbeda akan memiliki stakeholders yang berbeda, sehingga tingkat kelengkapan pengungkapan yang harus dilakukan berbeda, Agustina (2006). Perusahaan berbasis asing (PMA) mungkin melakukan pengungkapan yang lebih luas dibanding perusahaan yang berbasis dalam negeri (PMDN). Hal ini dikarenakan, pertama perusahaan berbasis asing mendapatkan pelatihan yang lebih baik (misalnya dalam bidang akuntansi) dari perusahaan induknya di luar negeri, kedua perusahaan berbasis asing mungkin mempunyai sistem akuntansi yang lebih efisien untuk memenuhi kebutuhan pengendalian internal dan kebutuhan informasi perusahaan induknya, ketiga perusahaan asing memiliki permintaan informasi yang lebih besar dari pelanggan, pemasok, analisis dan masyarakat pada umumnya. Perusahaan-perusahaan dengan status yang berbeda akan memiliki stakeholder yang berbeda, sehingga tingkat kelengkapan pengungkpan wajib laporan keuangan yang diungkap juga berbeda. Status Perusahaan dihitung menggunakan variabel dummy, skor 1 untuk penanaman modal dalam negeri dan skor untuk jika penanaman modal asing (Agustina, 2006).

\subsection{Indeks Wallace}

Indeks Wallace adalah instrumen yang digunakan untuk mengukur berapa banyak informasi laporan keuangan yang material yang diungkap oleh perusahaan. Semakin banyak item yang diungkap oleh perusahaan, semakin banyak juga angka indeks yang diperoleh perusahaan. Perusahaan dengan angka indeks yang lebih tinggi menunjukkan bahwa perusahaan tersebut telah melakukan praktek pengungkapan secara lebih komprehensif dibandingkan perusahaan yang lain. Semakin banyak item yang diungkapkan oleh perusahaan, semakin banyak pula angka indeks yang diperoleh perusahaan tersebut. Perusahaan dengan angka indeks yang lebih tinggi menunjukkan bahwa perusahaan tersebut melakukan praktik pengungkapan secara lebih komprehensif dibandingkan perusahaan lain (Dibiyantoro, 2011).

\subsection{Kerangka Berpikir}

Faktor-faktor yang akan diteliti antara lain yaitu leverage, likuiditas, profitabilitas, struktur kepemilikan saham publik dan status perusahaan yang dibentuk melalui hubungan antar variabel $\mathrm{X}$ dan variabel $\mathrm{Y}$. 


\section{Buana Akuntansi}

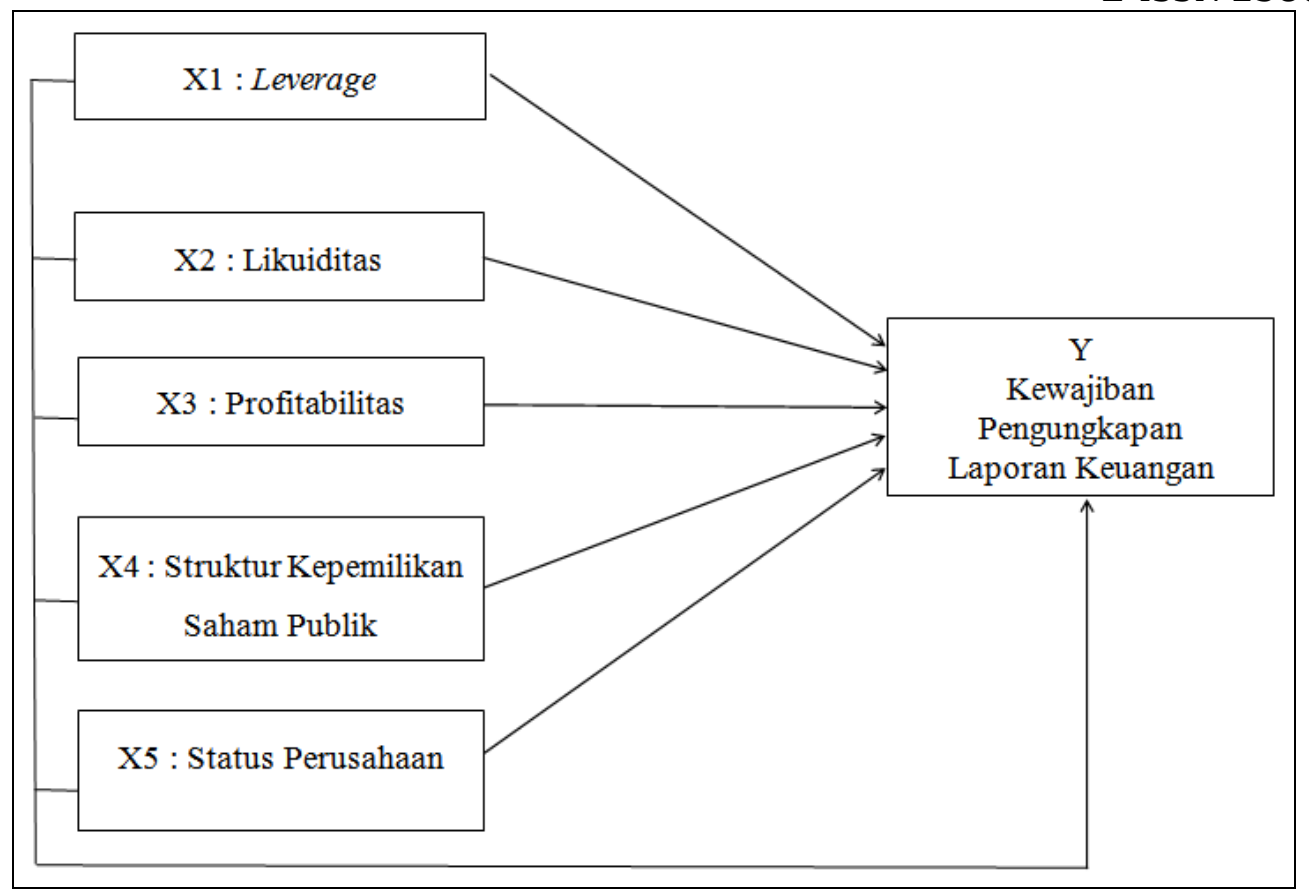

Gambar 1: Menjelaskan tentang Variabel $\mathrm{X}$ dan $\mathrm{Y}$

Penjelasan hubungan antar variabel dinyatakan dalam hipotesis alternatif (ha) berikut ini:

$\mathrm{H} 1=$ Leverage berpengaruh signifikan terhadap Kewajiban Pengungkapan Laporan

Keuangan

H2=Likuiditas berpengaruh signifikan terhadap Kewajiban Pengungkapan Laporan

Keuangan

H3=Profitabilitas berpengaruh signifikan terhadap Kewajiban Pengungkapan Laporan Keuangan

H4=Struktur Kepemilikan Saham Publik berpengaruh signifikan terhadap Kewajiban Pengungkapan Laporan Keuangan

H5=Status Perusahaan berpengaruh signifikan terhadap Kewajiban pengungkapan Laporan Keuangan

\section{Metodologi Penelitian}

\subsection{Jenis Penelitian}

Jenis penelitian ini menggunakan jenis penelitian asosiatif. Penelitian asosiatif adalah penelitian yang bertujuan untuk mengetahui hubungan dua variabel atau lebih guna untuk mengetahui hubungan variabel terikat yaitu kewajiban pengungkapan laporan keuangan dengan variabel bebas yaitu leverage, likuiditas, profitabilitas, struktur kepemilikan saham publik dan status perusahaan. Penelitian dilakukan di Bursa Efek Indonesia (BEI) yang beralamat di Gedung Bursa Efek Indonesia, Tower 1 - Lantai 6, Jl. Jend Sudirman Kav. 52-53, Jakarta Selatan - 12190, Indonesia. Penelitian ini menggunakan pendekatan kuantitatif dengan riset survei. Pertimbangan ini atas berbagai faktor yang akan memperlancar pengumpulan data dalam penelitian seperti proses dalam pengambilan data, penggunaan dana yang tidak terlalu besar serta penghematan waktu dan tenaga yang dipergunakan. 


\section{Buana Akuntansi}

FIDIATUR \& RIDWAN

Vol. 5 No. 1

ISSN 2528-1119

E-ISSN 2580-5452

\subsection{Metode Pengumpulan Data}

Metode pengumpulan data menggunakan studi kepustakaan yang dapat diperoleh dari buku, literatur, artikel, jurnal, dan hasil penelitian terdahulu dan dokumen-dokumen berupa laporan tahunan dan laporan keuangan yang dapat diakses melalui web www.idx.co.id.

\subsection{Teknik Pengambilan Sampel}

Penelitian ini menggunakan teknik yang didasarkan pada teknik purposive sampling yaitu yaitu teknik penentuan sampel dengan pertimbangan tertentu (Sugiyono, 2016, hal. 122). Adapun kriteria perusahaan Pulp dan Kertas yang terpilih untuk dijadikan sebagai sampel penelitian yaitu: (1) perusahaan Pulp dan Kertas yang terdaftar di Bursa Efek Indonesia selama periode 2013-2017; dan (2) Perusahaan yang memiliki kelengkapan data sesuai dengan kebutuhan, seperti laporan keuangan lengkap yang telah diaudit dan laporan tahunan selama periode 2013-2017.

Tabel 1. Data Sampel Perusahaan

\begin{tabular}{|c|c|l|}
\hline No & Kode Saham & \multicolumn{1}{c|}{ Nama Emiten } \\
\hline 1 & ALDO & PT Alkindo Naratama Tbk \\
\hline 2 & FASW & PT Fajar Surya Wisesa Tbk. \\
\hline 3 & INKP & PT Indah Kiat Pulp \& Paper Tbk. \\
\hline 4 & INRU & PT Toba Pulp Lestari Tbk. \\
\hline 5 & KBRI & PT Kertas Basuki Rachmat Indonesia Tbk. \\
\hline 6 & KDSI & PT Kedawung Setia Industrial Tbk. \\
\hline 7 & SPMA & PT Suparma Tbk. \\
\hline 8 & TKIM & PT Pabrik Kertas Tjiwi Kima Tbk. \\
\hline 9 & ALDO & PT Alkindo Naratama Tbk \\
\hline 10 & FASW & PT Fajar Surya Wisesa Tbk. \\
\hline
\end{tabular}

Sumber: Data BEI (2019)

Sampel perusahaan ditetapkan berdasarkan kriteria sebanyak 8 (delapan perusahaan).

\subsection{Operasionalisasi Variabel Penelitian}

Variabel Kewajiban pengungkapan Laporan Keuangan $(\mathrm{Y})$ yaitu penyampaian informasi laporan keuangan yang wajib dilaporkan sesuai dengan peraturan Otoritas Jasa Keuangan (OJK). Variabel ini dihitung dengan menggunakan indeks Wallace:

Indeks Wallace $=\frac{\mathrm{n}}{\mathrm{k}} x 100 \%$

Keterangan:

$\mathrm{n}$ = Jumlah item yang diungkap perusahaan

$\mathrm{k}=$ Jumlah item yang seharusnya diungkap berdasarkan peraturan

Berdasarkan Peraturan No. 30/SEOJK.04/2016 tentang Bentuk dan Isi Laporan Tahunan Emiten atau Perusahaan Publik, jumlah item yang wajib diungkapkan terdiri dari Ikhtisar Data Keuangan Penting 17 item, Informasi Saham 4 item, Laporan Direksi 4 item, Laporan Komisaris 6 item, Profil Perusahaan 19 item, Analisis dan Pembatasan Manajenen 17 item, Tata Kelola Emiten 16 item, Tanggungjawab Sosial 3 item, Laporan Keuangan Yang di Audit dan Surat Pernyataan Laporan Tahunan (OJK, 2016). Total item yang harus diungkap sebanyak 88 item.

Variabel Leverage (X1) yaitu kemampuan suatu perusahaan dalam memenuhi segala kewajiban finansialnya baik jangka panjang maupun jangka pendeknya. Variabel ini diukur menggunakan rasio hutang (debt ratio) dengan rumus berikut ini: 


\section{Buana Akuntansi}

Debt Equity Ratio $=\frac{\text { Total Debt }}{\text { Total Equity }}$ X100\%

Variabel Likuiditas (X2) yaitu rasio yang digunakan untuk mengukur seberapa likuidnya suatu perusahaan. Variabel ini diukur menggunakan rasio lancar (current ratio) dengan rumus berikut ini:

Current Ratio $=\frac{\text { Aktiva Lancar (Current Assets) }}{\text { Utang Lancar (Current Liabilitie s) }}$

Variabel Profitabilitas (X3) yaitu kemampuan suatu perusahaan untuk memperoleh keuntungan (profit) yang bertujuan untuk mengukur efisiensi aktivitas perusahaan dan kemampuan perusahaan untuk memperoleh keuntungan. Variabel ini diukur dengan menggunakan ROA (Return On Asset) dengan rumus berikut ini:

ROA $=\frac{\text { Laba bersih sesudah pajak }}{\text { total aktiva }} \times 100 \%$

Variabel Kepemilikan Saham Publik (X4) yaitu struktur kepemilikan saham oleh publik yang menggambarkan tingkat kepemilikan perusahaan oleh masyarakat publik. Variabel ini ditunjukkan dengan persentase saham yang dimiliki oleh publik yang dihitung dengan cara membandingkan antara jumlah saham yang dimiliki oleh masyarakat (publik) dengan total saham perusahaan yang beredar.

Variabel Status Perusahaan (X5) yaitu perusahaan dengan status yang berbeda akan memiliki stakeholders' yang berbeda sehingga tingkat kelengkapan pengungkapan yang harus dilakukan berbeda (Agustina, 2006).

\subsection{Metode Analisis Data}

Metode analisis data menggunakan regresi data panel. Data panel adalah gabungan antaradata runtut waktu (time series) dan data silang (cross section). Model pertama tidak menggunakan dummy dalam persamaan regresi sedangkan model kedua menggunakan variabel dummy ke dalam persamaan regresi (Basuki, 2016). Pemilihan model atas data panel dilakukan dengan menggunakan uji chow, uji random, dan uji Lagrange Multiplier (LM) jika diperlukan. Setelah pemilihan metode dan pembentukan model regresi dilakukan, perlu di uji kelayakan suatu model dalam menguji hipotesis yang diajukan. Mengingat data panel merupakan gabungan dari data time series dan cross section, maka untuk menguji hipotesishipotesis yang telah dirumuskan dalam penelitian ini dituliskan dengan model regresi sebagai berikut:

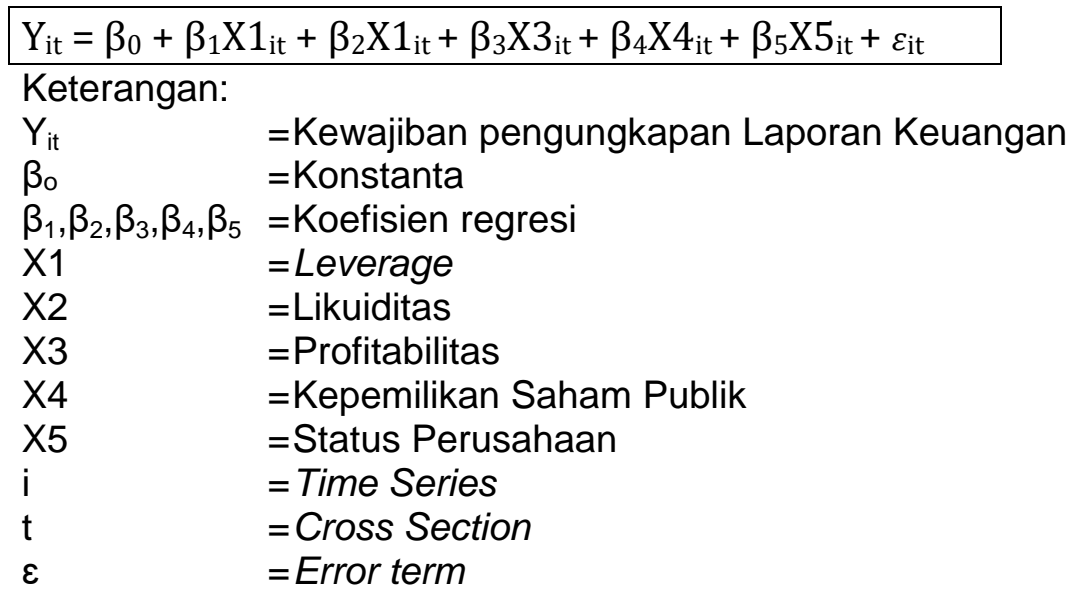




\section{Buana Akuntansi}

FIDIATUR \& RIDWAN

Vol. 5 No. 1

ISSN 2528-1119

E-ISSN 2580-5452

4. Analisis dan Pembahasan

4.1. Statistis Deskriptif

Penelitian dilakukan dengan sampel pada objek penelitian yaitu leverage, likuiditas, profitabilitas, kepemikan saham publik, status perusahaan dan kewajiban pengungkapan laporan keuangan yang ditampilkan sebarannya melalui analisis statistik deskriptif berikut ini.

Tabel 2. Hasil Statistik Deskriptif

\begin{tabular}{|c|c|c|c|c|c|c|}
\hline & $Y$ & DER & CR & ROA & KP & SP \\
\hline Mean & 0.759625 & 1.545 .950 & 1.343 .250 & 0.020650 & 0.262575 & 0.625000 \\
\hline Median & 0.778500 & 1.594 .500 & 1.356 .000 & 0.021000 & 0.250000 & 1.000 .000 \\
\hline Maximum & 0.818000 & 2.997 .000 & 3.652 .000 & 0.124000 & 0.668000 & 1.000 .000 \\
\hline Minimum & 0.602000 & 0.138000 & 0.337000 & -0.108000 & 0.040000 & 0.000000 \\
\hline Std. Dev. & 0.052879 & 0.525232 & 0.576588 & 0.050520 & 0.145622 & 0.490290 \\
\hline Skewness & -0.965714 & 0.144438 & 1.612 .269 & -0.514821 & 0.543232 & -0.516398 \\
\hline Kurtosis & 3.409 .954 & 4.112 .711 & 8.015 .165 & 3.843 .290 & 2.989 .457 & 1.266 .667 \\
\hline Jarque-Bera & 6.497 .455 & 2.202 .625 & 5.924 .922 & 2.952 .167 & 1.967 .528 & 6.785 .185 \\
\hline Probability & 0.038824 & 0.332434 & 0.000000 & 0.228531 & 0.373901 & 0.033621 \\
\hline Sum & 3.038 .500 & 6.183 .800 & 5.373 .000 & 0.826000 & 1.050 .300 & 2.500 .000 \\
\hline Sum Sq. Dev. & 0.109049 & 1.075 .889 & 1.296 .568 & 0.099539 & 0.827028 & 9.375 .000 \\
\hline Observations & 40 & 40 & 40 & 40 & 40 & 40 \\
\hline
\end{tabular}

Sumber: Output Eviews Diolah Peneliti (2019)

Variabel Kewajiban pengungkapan Laporan Keuangan $(Y)$ memiliki nilai terendah dan tertinggi sebesar 0,602000 dan 0,818000. Nilai rata-rata kewajiban pengungkapan sebesar 0,759625 . Nilai terendah merupakan kewajiban pengungkapan dari PT Fajar Surya Wisesa tahun 2013 sedangkan nilai tertinggi adalah PT Alkarindo Naratama Tbk tahun 2014. Kewajiban pengungkapan didapat dengan menghitung total informasi yang di ungkap di bagi dengan total informasi yang harus di ungkapkan. Variabel Leverage (X1) memiliki rata-rata Debt-to Equity Ratio tahun 2013-2017 sebesar 1,545950 dengan nilai terendah dan tertinggi masing-masing sebesar 0,138000 dan 2,997000. PT Kertas Basuki Rachmat Indonesia Tbk memiliki Debt-to Equity Ratio terendah pada tahun 2013 sedangkan Debt-to Equity Ratio tertinggi pada tahun 2017 adalah PT Kertas Basuki Rachmat Indonesia Tbk. Variabel Likuditas (X2) memiliki ratarata Current Ratio tahun 2013-2017 sebesar 1,343250 dengan nilai terendah dan tertinggi masing-masing sebesar 0,337000 dan 3,652000. PT Kertas Basuki Rachmat Indonesia Tbk memiliki profitabilitas terendah pada tahun 2013 dan PT Suparma Tbk memiliki profitabilitas tertinggi pada tahun 2014. Variabel Profitabilitas (X3) memiliki rata-rata Return to Asset tahun 2013-2017 sebesar 0,020650 dengan nilai terendah dan tertinggi masing-masing sebesar 0,108000 dan 0,124000. PT Kertas Basuki Rachmat Indonesia Tbk memiliki Return to Asset terendah pada tahun 2017 dan PT Fajar Surya Wisesa Tbk memiliki Return to Asset tertinggi pada tahun 2015. Variabel Kepemilikan Saham Publik (X4) memiliki rata-rata saham Kepemilikan Publik sebesar 0,262575. Kepemilikan Saham Publik terendah sebesar 0,040000 pada perusahaan PT Toba Pulp Lestari Tbk pada tahun 2013 sedangkan Kepemilikan Publik tertinggi sebesar 0,668000 pada perusahaan PT Kertas Basuki Rachmat Indonesia Tbk pada tahun 2013. Variabel Status Perusahaan (X5) memiliki rata-rata Status Perusahaan sebesar 0,625000. Status Perusahaan dengan penanaman modal asing yaitu dengan PT Toba Pulp Lestari Tbk, PT Kertas Basuki Rachmat Indonesia Tbk, dan PT Suparma Tbk sedangkan sisanya menggunakan penanaman modal dalam negeri. 


\section{Buana Akuntansi}

FIDIATUR \& RIDWAN

Vol. 5 No. 1

ISSN 2528-1119

E-ISSN 2580-5452

\subsection{Pemilihan Model Regresi Data Panel}

Pemilihan model regresi data panel dapat dilakukan menggunakan 3 (tiga) pendekatan dengan rangkuman hasil sebagai berikut:

Tabel 3. Rangkuman Hasil Uji Estimasi Regresi Data Panel

\begin{tabular}{|c|c|c|}
\hline Metode & Model Estimasi yang Diuji & Hasil / Keputusan \\
\hline Uji Chow (uji statistik F) & CEM vs FEM & Fixed-Effect Model \\
\hline Uji Hausman & CEM vs REM & Fixed-Effect Model \\
\hline Uji Lagrange Multiplier (LM) & FEM vs REM & 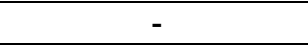 \\
\hline
\end{tabular}

Sumber: Output Eviews Diolah Peneliti (2019)

Hasil uji Chow dan Hausman menghasilkan keputusan pemilihan Fixed-Effect Model. Oleh karena itu, lagrange multiplier (LM) tidak perlu dilakukan sehingga pengujian hipotesis dengan analisis regresi data panel menggunakan Fixed-Effect Model.

\subsection{Uji Asumsi Klasik}

Uji asumsi klasik dilakukan melalui 4 (empat) tahapan. Uji asumsi klasik pertama yaitu normalitas data yang dilakukan dengan membandingkna nilai Jarque-Bera dengan kriteria penerimaan hipotesis yaitu $\mathrm{H}_{0}$ diterima jika nilai probabilitas Jarque-Bera pada hasil pengujian > 0,05 artinya data berdistribusi normal, atau sebaliknya.

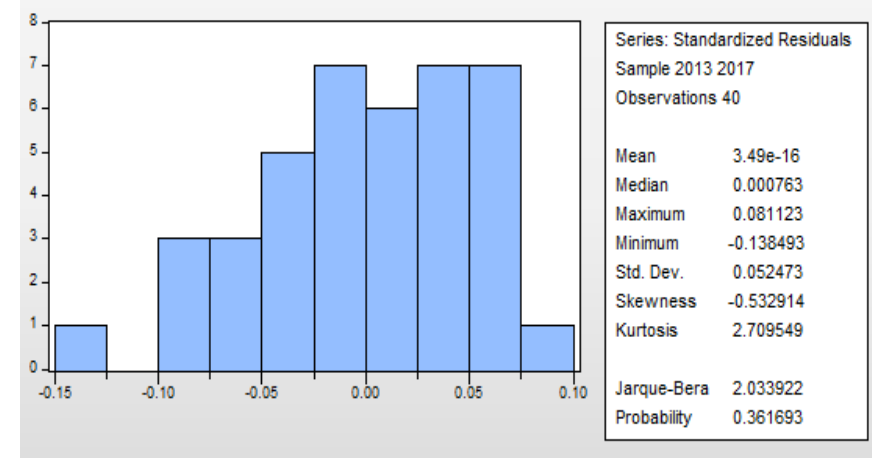

Gambar 2: Histogram Uji Normalitas

Sumber: Output Eviews Diolah Peneliti (2019)

Nilai dari Jarque-Bera sebesar 2,033922 dengan probability 0,361693 sehingga dapat dilihat bahwa probabilitas signifikansi Jarque-Bera lebih besar dari Alpha 0,05 sehingga data berdistribusi normal. Uji asumsi klasik yang kedua yaitu uji autokorelasi yang bertujuan untuk ada atau tidaknya penyimpangan asumsi klasik autokorelasi, yaitu korelasi yang terjadi antara residual pada satu pengamatan dengan pengamatan lain pada model regresi. Deteksi autokorelasi pada data panel dapat melalui uji Breusch-Godfrey Serial Correlation LM Test.

Tabel 4. Output Uji Autokorelasi Breusch-Godfrey Serial Correlation LM Test Breusch-Godfrey Serial Correlation LM Test:

F-statistic

Obs ${ }^{*}$-squared

Variable
2.864 .040

Prob. $F(2,32)$

6.073.016 Prob.Chi-Square(2)

Coefficient Std. Error
0.0717

0.0480

t-Statistic Prob. 


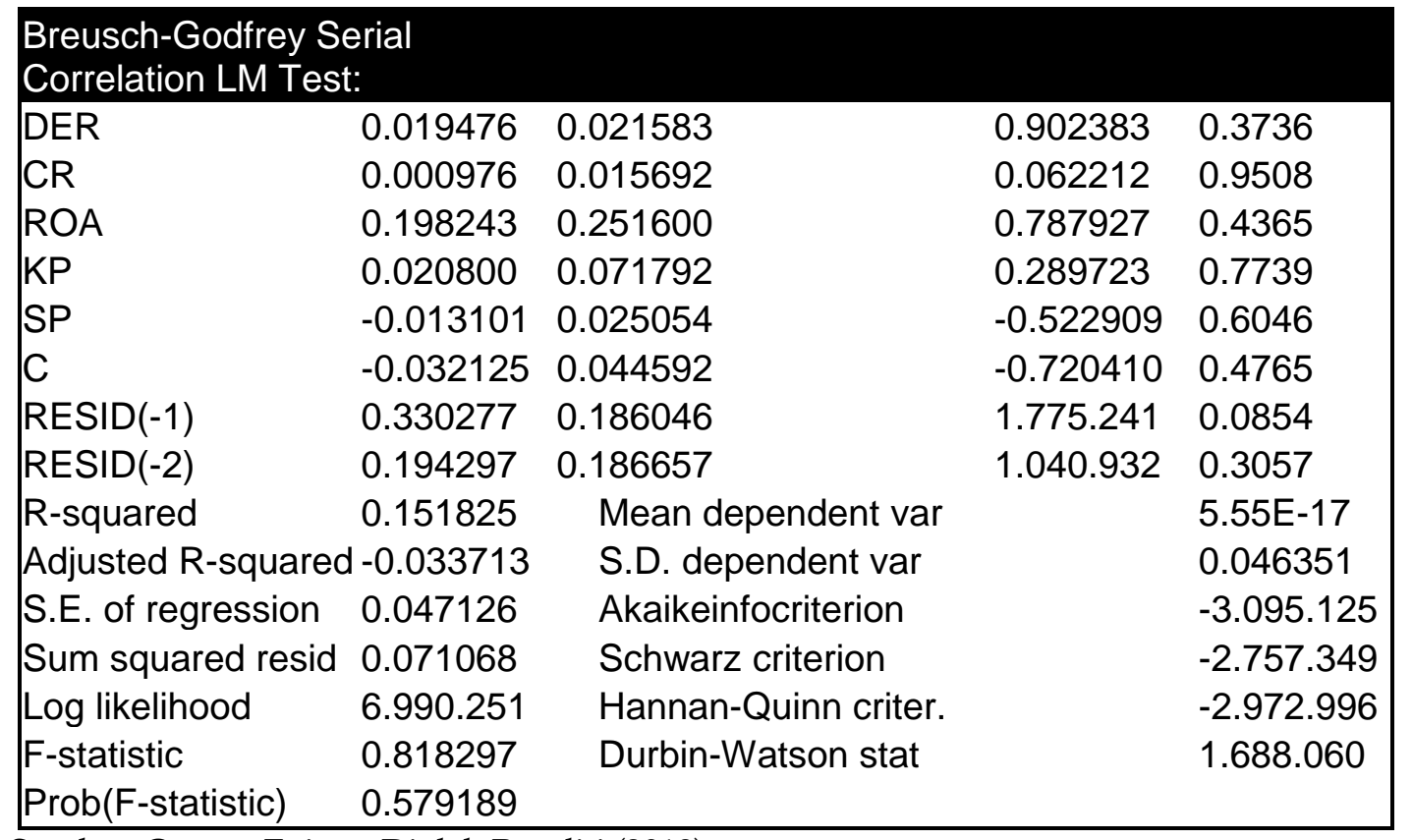

Sumber: Output Eviews Diolah Peneliti (2019)

Nilai Probabilitas $\mathrm{F}$ sebesar 0,0480 atau yang disebut juga dengan nilai $\mathrm{F}$ hitung. Nilai probabilitas $\mathrm{F}$ hitung lebih kecil dari tingkat alpha 0,05 (5\%) sehingga berdasarkan hasil uji hipotesis Ha diterima artinya terjadi masalah autokorelasi. Uji asumsi klasik yang ketiga yaitu uji heteroskedastisitas yang bertujuan untuk melihat apakah di dalam penelitian terdapat masalah heteroskedastisitas. Penelitian dikatakan memiliki masalah heteroskedastisitas apabila residual model yang diamati tidak memiliki varian yang konstan dari satu observasi ke observasi lainnya. Deteksi heteroskedastisitas pada data panel dapat melalui uji Breusch.

Tabel 5. Output Uji Heteroskedastisitas Breusch

\begin{tabular}{|lrll|}
\hline Heteroskedasticity & Test: Breusch-Pagan-Godfrey & \\
\hline F-statistic & 1.576 .764 & Prob. F(5,34) & 0.1930 \\
Obs ${ }^{\star}$ R-squared & 7.529 .227 & Prob. Chi-Square(5) & 0.1842 \\
Scaled explained SS 5.690.344 & Prob. Chi-Square(5) & 0.3375 \\
\hline
\end{tabular}

Sumber: Output Eviews Diolah Peneliti (2019)

Nilai Prob Obs*R-ssquare diketahui sebesar 0,1842 lebih besar daripada 0,05 artinya tidak mempunyai masalah heteroskedastisitas. Uji asumsi klasik yang keempat yaitu uji multikolinearitas. Masalah asumsi klasik regresi bukan hanya terletak kepada adanya hubungan antar data dalam satu varibel, tetapi juga hubungan antara sesama variabel bebas. Jika dua atau lebih variabel bebas dalam model regresi memiliki hubungan linier yang kuat, maka model regresi ini tergejala oleh kondisi multikolinearitas. Pendeteksian problem multikolinearitas dapat dilihat dari nilai Variance Inflation Factor (VIF), jika nilai VIF kurang dari 10, maka tidak ada gejala multikolinearitas atau sebaliknya, jika nilai VIF lebih dari 10 dan nilai tolerance lebih dari 0,10, maka tidak ada gejala multikolinearitas. Untuk mengujinya menggunakan metode High pair-wise Correlation among Regressors. 


\section{Buana Akuntansi}

Tabel 6. Output Uji Multikolinearitas High Pair-Wise Correlation

\begin{tabular}{|llll|}
\hline Variance Inflation Factors & & & \\
\hline Variable & Coefficient & Uncentered & Centered \\
DER & Variance & VIF & VIF \\
CR & 0.000443 & 1.912 .804 & 1.934 .952 \\
ROA & 0.000247 & 8.530 .953 & 1.299 .172 \\
KP & 0.062630 & 2.963 .194 & 2.529 .706 \\
SP & 0.005633 & 8.193 .884 & 1.890 .334 \\
C & 0.000660 & 6.696 .187 & 2.511 .070 \\
\hline
\end{tabular}

Sumber: Output Eviews Diolah Peneliti (2019)

Hubungan antara variabel bebas tidak ada yang menunjukkan nilai korelasi $>0,90$ sehingga dapat disimpulkan bahwa data yang digunakan dalam penelitian ini terbebas dari masalah multikolinearitas. Pemilihan model berdasarkan uji estimasi model regresi data panel ditetapkan menggunakan Fixed-Effect Model (FEM) berdasarkan hasil uji Chow dan Hausman.

\subsection{Uji Hipotesis}

Berdasarkan penetapan estimasi model regresi data panel menggunakan Fixed-Effect Model (FEM), maka rangkuman hasil analisis regresi menghasilkan:

Tabel 7. Rangkuman Hasil Uji R ${ }^{2}$ dan Uji-F

\begin{tabular}{|llll|}
\hline R-squared & 0.120625 & Mean dependent var & 0.336723 \\
Adjusted R-squared & -0.008694 & S.D. dependent var & 0.035622 \\
S.E. of regression & 0.035777 & Sum squared resid & 0.043519 \\
F-statistic & 0.932769 & Durbin-Watson stat & 0.701638 \\
Prob(F-statistic) & 0.472149 & & \\
\hline
\end{tabular}

Sumber: Output Eviews Diolah Peneliti (2019)

Nilai Adjusted $R$ Squared menunjukkan seberapa besar variabel bebas mampu menjelaskan varian dari variabel terikat. Hasil analisis regresi secara keseluruhan menghasilkan skor -0,008694 yang menunjukkan bahwa variabel bebas yang terdiri dari Likuiditas, Debt-to Equity Ratio (DER), Return On Asset (ROA) Kepemilikan Publik (KP) dan Status Perusahaan (SP) tidak mampu menjelaskan kewajiban pengungkapan sebagai variabel dengan hasil negatif 0,8694 persen. Nilai $F_{\text {hitung }} 0,932769<F_{\text {tabel }} 2,65$ dan signifikansi $0,472149<0,05$ maka $\mathrm{H}_{0}$ ditolak sehingga dapat disimpulkan bahwa variabel bebas yang terdiri dari Likuiditas, Debt-to Equity Ratio, Return On Asset, Kepemilikan Saham Publik dan Status Perusahaan secara bersama-sama tidak berpengaruh signifikan terhadap variabel terikat yaitu Kewajiban pengungkapan Laporan Keuangan.

Tabel 8. Rangkuman Hasil Uji-t

\begin{tabular}{|c|c|c|c|c|}
\hline Variable & Coefficient & Std. Error & t-Statistic & Prob \\
\hline C & 0.839865 & 0.033300 & 2.522 .090 & 0.0000 \\
\hline $\mathrm{X} 1$ & -0.029331 & 0.013798 & -2.125 .713 & 0.0409 \\
\hline $\mathrm{X} 2$ & -0.011437 & 0.010044 & -1.138 .787 & 0.2628 \\
\hline X3 & -0.110898 & 0.167676 & -0.661382 & 0.5128 \\
\hline X4 & -0.098363 & 0.059766 & -1.645 .811 & 0.1090 \\
\hline X5 & 0.013737 & 0.024762 & 0.554757 & 0.5827 \\
\hline
\end{tabular}

Sumber: Output Eviews Diolah Peneliti (2019) 
- Hipotesis ke-1 menghasilkan koefisien regresi sebesar -0,029331, dengan probabilitas signifikansi sebesar 0,0409 diketahui kurang dari $\alpha=0,05$ sehingga menerima H1. Hipotesis ini secara statistik membuktikan leverage berpengaruh signifikan dan negatif terhadap kewajiban pengungkapan laporan keuangan.

- Hipotesis ke-2 menghasilkan koefisien regresi sebesar -0,011437, dengan probabilitas signifikansi sebesar 0,2628 diketahui lebih besar dari $\alpha=0,05$ sehingga menolak H2. Hipotesis ini secara statistik tidak membuktikan likuiditas berpengaruh signifikan terhadap kewajiban pengungkapan laporan keuangan.

- Hipotesis ke-3 menghasilkan koefisien regresi sebesar -0,110898, dengan probabilitas signifikansi sebesar 0,5125 diketahui lebih besar dari $\alpha=0,05$ sehingga menolak H3. Hipotesis ini secara statistik tidak membuktikan profitabilitas berpengaruh signifikan terhadap kewajiban pengungkapan laporan keuangan.

- Hipotesis ke-4 menghasilkan koefisien regresi sebesar -0,098363, dengan probabilitas signifikansi sebesar 0,1090 diketahui lebih besar dari $\alpha=0,05$ sehingga menolak H4. Hipotesis ini secara statistik tidak membuktikan kepemilikan saham publik berpengaruh signifikan terhadap kewajiban pengungkapan laporan keuangan.

- Hipotesis ke-5 menghasilkan koefisien regresi sebesar 0,013737, dengan probabilitas signifikansi sebesar 0,5827 diketahui lebih besar dari $\alpha=0,05$ sehingga menolak H5. Hipotesis ini secara statistik tidak membuktikan status perusahaan berpengaruh signifikan terhadap kewajiban pengungkapan laporan keuangan.

\subsection{Pembahasan}

Berdasarkan hasil uji-t atas variabel leverage, diperoleh probabilitas signifikansi sebesar 0,0409, nilai ini lebih kecil dari tingkat signifikansi sebesar 0,05 tetapi memiliki $t_{\text {hitung }}$ lebih kecil dari $t_{\text {tabel }}(1,69092)$ sehingga dapat disimpulkan bahwa leverage tidak berpengaruh signifikan terhadap kewajiban pengungkapan laporan keuangan. Ketidakmampuan Debt to Equity Ratio (DER) mempengaruhi kewajiban pengungkapan dikarenakan DER yang tinggi menunjukkan proporsi modal yang dimiliki lebih kecil daripada kewajiban perusahaan atau adanya ketergantungan yang tinggi terhadap pihak luar, hal ini mengindikasikan bahwa perusahaan akan meminimalisir informasi khususnya mengenai kewajiban (jangka pendek maupun panjang), sehingga jika dipublikasikan akan meragukan investor. Penelitian ini tidak sesuai dengan teori agensi yaitu hubungan keagenan antara prinsipal (kreditur) dengan agennya (perusahaan) menyatakan bahwa perusahaan akan memberikan informasi yang seluas-luasnya mengenai kondisi perusahaan kepada krediturnya. Harapannya kreditur akan lebih mengetahui dan memahami perusahaan dalam kaitannya dengan kredit yang diberikan, sehingga perubahan DER memiliki pengaruh yang tidak signifikan untuk dapat mempengaruhi kewajiban pengungkapan laporan keuangan perusahaan. Temuan ini sesuai dengan hasil penelitian yang menunjukkan bahwa leverage tidak berpengaruh signifikan terhadap praktik kewajiban pengungkapan (Pradipta, Topowijono, \& Azizah, 2016; Astina M., Hardi, \& A., 2017).

Berdasarkan hasil uji-t atas variabel likuiditas, diperoleh probabilitas signifikansi sebesar 0,2628, nilai ini lebih besar dari tingkat signifikansi sebesar 0,05 sehingga dapat disimpulkan bahwa likuiditas tidak berpengaruh signifikan terhadap kewajiban pengungkapan laporan keuangan. Tingginya current ratio seharusnya berpengaruh positif terhadap pengungkapan laporan keuangan, karena ini menandakan perusahaan dalam kondisi yang baik dan likuid dalam pemenuhan kewajibannya. Temuan ini sesuai dengan hasil penelitian yang menunjukkan 
bahwa likuiditas tidak berpengaruh signifikan terhadap praktik kewajiban pengungkapan (Pradipta, Topowijono, \& Azizah, 2016; Astina M., Hardi, \& A., 2017).

Berdasarkan hasil uji-t atas variabel profitabilitas, diperoleh probabilitas signifikansi sebesar 0,5125 , nilai ini lebih besar dari tingkat signifikansi sebesar 0,05 sehingga dapat disimpulkan bahwa profitabilitas tidak berpengaruh signifikan terhadap kewajiban pengungkapan laporan keuangan. Hasil penelitian ini menunjukkan bahwa kinerja manajemen dalam mengelola kekayaan perusahaan tidak berpengaruh terhadap kewajiban pengungkapan. Rendahnya tingkat profitabilitas memperlihatkan tidak efektifnya aktivitas yang dijalankan perusahaan sehingga enggan untuk mengungkapkan laporan keuangannya secara berlebih karena dikhawatirkan akan kehilangan para investornya, hal ini tentunya sejalan dengan teori akuntansi positif dimana manajer akan cenderung melaporkan laba secara konservatif atau secara hatihati untuk menghindari pengawasan yang lebih ketat dari pemerintah, para analis, dan masyarakat khususnya dalam rangka kewajiban pengungkapan dalam laporan keuangan. Temuan ini sesuai dengan hasil penelitian yang menunjukkan bahwa profitabilitas tidak berpengaruh signifikan terhadap praktik kewajiban pengungkapan (Pradipta, Topowijono, \& Azizah, 2016), sementara bertolak belakang dengan hasil yang menunjukkan pengaruh positif profitabilitas atas kelengkapan pengungkapan laporan keuangan (Astina M., Hardi, \& A., 2017).

Berdasarkan hasil uji-t atas variabel kepemilikan saham publik, diperoleh probabilitas signifikansi sebesar 0,1090, nilai ini lebih besar dari tingkat signifikansi sebesar 0,05 sehingga dapat disimpulkan bahwa kepemilikan saham publik tidak berpengaruh signifikan terhadap kewajiban pengungkapan laporan keuangan. Dilihat dari hasil uji kepemilikan saham publik tidak berpengaruh signifikan namun memberikan sinyal positif dalam mempengaruhi kewajiban pengungkapan. Semakin besar struktur kepemilikan saham oleh publik maka akan berdampak pada peningkatan permintaan informasi oleh eksternal yang menanamkan modal pada perusahaan serta semakin banyak item-item informasi yang mendetail pada laporan tahunan. Temuan ini tidak sesuai dengan hasil penelitian yang menunjukkan kontribusi faktor saham publik terhadap kelengkapan pengungkapan laporan keuangan (Wahyuningsih, Arifati, \& Raharjo, 2016).

Berdasarkan hasil uji-t atas variabel status perusahaan, diperoleh probabilitas signifikansi sebesar 0,5827, nilai ini lebih besar dari tingkat signifikansi sebesar 0,05 sehingga dapat disimpulkan bahwa status perusahaan tidak berpengaruh signifikan terhadap kewajiban pengungkapan laporan keuangan. Status Perusahaan berarti tidak memiliki porsi yang besar dalam mempengaruhi perusahaan untuk melaporkan kewajiban pengungkapannya. Namun dari hasil positif yang didapat menandakan perusahaan dengan modal dalam negeri lebih cenderung tinggi dalam kewajiban pengungkapannya.

\section{Kesimpulan, Keterbatasan, dan Saran}

Berdasarkan hasil penelitian dan pembahasan, maka penelitian ini disimpulkan sebagai berikut:

1) Hasil pengujian parsial (uji-t) masing-masing variabel leverage, likuiditas, profitabilitas, kepemilikan saham publik dan status perusahaan terhadap variabel kewajiban pengungkapan dalam laporan keuangan tidak terbukti berpengaruh signifikan. Faktorfaktor di atas yang mencerminkan pengukuran kinerja keuangan dan pasar tidak mampu memprediksi kewajiban pengungkapan dalam laporan keuangan dengan pendekatan indeks wallace. Temuan penelitian tidak mendukung teori agensi, dimana besarnya pengungkapan informasi keuangan dan informasi relevan lainnya dalam penelitian ini tidak mampu mengevaluasi faktor-faktor leverage, likuiditas, profitabilitas, kepemilikan saham publik dan status perusahaan. 
2) Hasil pengujian simultan (uji-F) atas faktor-faktor yang terdiri dari leverage, likuiditas, profitabilitas, kepemilikan saham publik dan status perusahaan terhadap variabel kewajiban pengungkapan laporan keuangan menunjukkan nilai probability yang lebih besar dari (>) 0,05 dan menghasilkan nilai adjusted $R^{2}$ sebesar minus 0,8694 persen. Model ini yang melibatkan faktor yang terdiri dari leverage, likuiditas, profitabilitas, kepemilikan saham publik dan status perusahaan juga tidak mampu memprediksi kewajiban pengungkapan dalam laporan keuangan.

Berdasarkan kesimpulan dari penelitian, maka penelitian ini dapat memberikan saran sebagai berikut:

1) Manajemen dapat mempertimbangkan dalam melakukan pengungkapan yang lebih banyak lagi serta lebih memperhatikan aturan-aturan yang telah ditetapkan oleh OJK (Otoritas Jasa Keuangan) dalam penyusunan dan pengungkapan wajib atas laporan keuangan.

2) Sebelum melakukan investasi dan mengambil keputusan, hendaknya tidak hanya mengandalkan data mengenai Debt-to Equity Ratio (DER), Current Ratio, Return On Asset (ROA), Kepemilikan Publik dan Status Perusahaan, tetapi perlu juga memperhatikan faktor-faktor lain yaitu dari faktor keuangan maupun faktor nonkeuangan, seperti common stock ratio, pendapatan per share dan margin laba bruto, porsi saham asing, umur perusahaan, status perusahaan, nilai persentase, jenis industri, penerbitan sekuritas, waktu terdaftar dan persentase manajerial sehingga informasi yang di dapat akan lebih relevan dan mencerminkan keadaan perusahaan yang sebenarnya.

3) Penelitian mendatang dapat menambah jumlah sampel dan memperpanjang periode agar dapat mengevaluasi temuan penelitian ini. Berdasarkan nilai adjusted $\mathrm{R}^{2}$ sebesar minus 0,8694 persen bahwa terdapat variabel lain yang tidak diteliti yang berpengaruh dalam kewajiban pengungkapan dalam laporan keuangan maka disarankan untuk menambahkan variabel lainnya.

\section{Daftar Pustaka}

Adhani, Y. S., \& Subroto, B. (2013). Relevansi Nilai Informasi Akuntansi. Jurnal Ilmiah Mahasiswa FEB, 2 (2), 1-15.

Agustina, D. (2006). Analisa Beberapa Faktor yang Mempengaruhi Kelengkapan Laporan Keuangan Perusahaan Jasa Transportasi, Perdagangan dan Manufaktur yang Tercatat di Bursa Efek Jakarta. Jurnal Bisnis dan Akuntansi, 8 (2), 219-246.

Ant, Jurnalis. (2018, Januari 10). Industri Kertas Cetak Melambat di Dunia Serba Digital, Online. Retrieved April 12, 2019, from Oke Finance: https://economy.okezone.com/read/2018/01/ 10/320/1842765/industri-kertas-cetak-melambat-di-dunia-serba-digital

Astina M., J., Hardi, H., \& A., A. A. (2017). Faktor-Faktor Yang Mempengaruhi Kelengkapan Pengungkapan Laporan Keuangan Pada Perusahaan Manufaktu Yang Terdaftar Di BEI Tahun 2011-2013. JOM Fekon, 4 (1), 1051-1065.

Badan Litbang Kementerian Perindustrian. (2018, November 06). Industri Pulp dan Kertas Dipacu Manfaatkan Teknologi Ramah Lingkungan, Online. Retrieved April 19, 2019, from Berita/Litbang Artikel BPPI: http:/ / bppi.kemenperin.go.id/blog/industri-pulp-dan-kertas/

Basuki, A. T. (2016). Analisis Regresi Dalam Penelitian Ekonomi E Bisnis: Dilengkapi Aplikasi SPSS $\mathcal{E}$ EVIEWS. Depok: PT Rajagrafindo Persada. 


\section{Buana Akuntansi}

BEI. (2015, Desember). Panduan IPO Go-Public. Retrieved April 19, 2019, from IDX: https://www.idx.co.id/Portals/0/StaticData/Information/ForCompany/Panduan-GoPublic\%20_Dec-2015.pdf Chariri, A., \& Ghozali, I. (2014). Teori Akuntansi. Semarang: UNDIP.

Dani Jumadil Akhir, Jurnalis. (2018, September 12). 40 Emiten 'Malas' Serahkan Laporan Keuangan Semester I-2018, Ini Daftarnya, Online. Retrieved April 12, 2019, from Oke Finance: https:/ / economy.okezone.com/read/2018/09/12/278/1949219/40-emiten-malas-serahkanlaporan-keuangan-semester-i-2018-ini-daftarnya

Dibiyantoro. (2011). Pengaruh Struktur Modal dan Profitabilitas Perusahaan terhadap Mandatory Disclosure Financial Statement pada Perusahaan Manufaktur yang Terdaftar di BEI. Jurnal Ekonomi dan Informasi Akuntansi, 1 (2), 174-199.

Harahap, S. S. (2009). Analisis Kritis Atas Laporan Keuangan. Jakarta: Raja Grafindo Persada.

Hery. (2017). Teori Akuntansi Dasar 1 E 2. Jakarta: PT. Grasindo.

Kasmir, D. (2016). Analisis Laporan Keuangan. Jakarta: PT. Rajagrafindo Persada.

Kementerian Perindustrian RI. (2016, Oktober 19). Industri Pulp dan Kertas Berpotensi Tumbuh Signifikan, Online. Retrieved Maret 19, 2019, from Siaran Pers: https://kemenperin.go.id/ artikel/16331/Industri-Pulp-dan-Kertas-Berpotensi-Tumbuh-Signifikan--

Mawardi, R. (2018, Agustus 30). Economic Consequences and Positive Accounting Theory, Online. Retrieved April 19, 2019, from Perbanas Institute: https://dosen.perbanas.id/economicconsequences-and-positive-accounting-theory/

OJK. (2016). Peraturan Nomor 30/SEOJK.04/2016 tentang Bentuk dan Isi Laporan Tahunan Emiten atau Perusahaan Publik. Jakarta: Otoritas Jasa Keuangan.

OJK. (2016). Peraturan Otoritas Jasa Keuangan Nomor 29/POJK.04/2016 tentang Laporan Tahunan Emiten Atau Perusahaan Publik. Jakarta: Otoritas Jasa Keuangan.

Pradipta, F., Topowijono, \& Azizah, D. F. (2016). Pengaruh Ukuran Perusahaan, Leverage, Profitabilitas, dan Likuiditas Terhadap Luas Kewajiban pengungkapan Laporan Keuangan. Jurnal Administrasi Bisnis, 36 (1), 101-110.

Subramanyam, K. R. (2014). Financial Statement Analysis (11th / International ed.). New York: McGraw-Hill.

Sugiyono. (2016). Metode Penelitian Kombinasi (Mixed Methods). (M. Sutopo, Ed.) Bandung: CV. Alfabeta.

Supriyono, R. (2018). Akuntansi Keperilakuan. Yogyakarta: Gajah Mada University Press.

Wahyuningsih, W., Arifati, R., \& Raharjo, K. (2016). Pengaruh Likuiditas, Leverage, Profitabilitas, Porsi Saham Publik, Ukuran Perusahaan dan Umur Perusahaan Terhadap Kelengkapan Pengungkapan Laporan Keuangan Pada Perusahaan Manufaktur Yang Terdaftar di Bursa Efek Indonesia Periode Tahun 2009-2014. Journal Of Accounting, 2 (2)

Yanti. (2018). Analisa Pengaruh Faktor-Faktor Pembentuk Fee Ijarah (PSAK 107) Terhadap Portofolio Rahn Emas Di Bank Syariah. Jurnal Buana Akuntansi , 3 (1), 24-55. 